\title{
EL SIMBOLISMO BAJO LA PLUMA DE EMILIA PARDO BAZÁN, Y UN TEXTO OLVIDADO («UN POETA DE LA HORA PRESENTE. VERHAEREN»).
}

JAVIER LÓPEZ QUINTÁNS IES «Ramón Ma Aller Ulloa(Lalin)» javierlopezquintans@yahoo.es

\section{RESUMEN}

La producción de Emilia Pardo Bazán ofrece numerosos comentarios acerca del Simbolismo y dos corrientes afines, Parnasianismo y Decadentismo. El presente trabajo realiza un recorrido sobre tales apreciaciones, y edita finalmente un texto olvidado de la autora: «Un poeta de la hora presente. Verhaeren».

Palabras Clave:Pardo Bazán, Simbolismo, Decadentismo, edición.

\section{AbSTRACT}

The production of Emilia Pardo Bazán offers numerous comments about the symbolism and two related streams, Parnasianism and Decadentism. This paper takes a journey on such findings, and edits a forgotten text of the author: «A poet of the current hour. Verhaeren

KeY words:Pardo Bazán, Symbolism, Decadentism, edition. 
El Simbolismo Bajo la Pluma De Emilia Pardo Bazán, Y Un Texto Olvidado («Un Poeta De La Hora Presente. Verhaeren»)

En el cenáculo del Simbolismo, la declamación sucumbe y el mundo destilado en una atmófera objetiva perece, bajo los auspicios de la idea llena de sugestión y evocaciones. La evocación sensible pierde su fruto en un nuevo universo lírico. Un ritmo musical y una rima acompasada llega con nuevas teclas de artificiosidad: «Le Rythme : l'ancienne métrique avivée; un désordre savamment ordonné ; la rime illucescente et martelée comme un bouclier d'or et d'airain, auprès de la rime aux fluidités absconses». He aquí algunos de los ingredientes que Jean Moréas cocinaba en el Manifiesto simbolista, tal y cual este se ofreció en Le Figaro un sábado 18 de septiembre de 1886 (Supplément littéraire, p.1-2). Nueva tendencia de vísceras revulsivas, como negación supone aquella corriente que emerge ante las aguas remansadas del pensamiento dominante, fijando su puntal, «à l'inéluctable fin de l'école immédiatement antérieure».

Andamiaje plegado a disputas febrilmente enconadas que condujeron a recalificaciones y derroteros varios, como fue el sendero trazado por René Ghil con su Traité $d u$ verb (1885). El prólogo, firmado por Mallarmé, delata la sensibilidad nueva que se forjaba en esos momentos, bajos pensamientos como los que suscribe ( «Je dis : une fleur ! et, hors de l'oubli où ma voix relègue aucun contour, en tant que quelque chose d'autre que les calices sus, musicalement se lève, idée rieuse ou altière l'absente de tous bouquets»). Ghil disecciona el valor de la palabra, desmembrándola en evocaciones cromáticas anegadas de sugestivas emanaciones; emanaciones que empapan a Rimbaud, asociando cada vocal a un color:

A noir, E blanc, I rouge, $\mathrm{U}$ vert, $\mathrm{O}$ bleu : voyelles, Je dirai quelque jour vos naissances latentes

Observemos el poder de los sentidos, ubicándose en su trono fragante del universo simbolista. Ghil y Moréas participarán de desencuentros de heterogénea resonancia, afluyendo en la apostasía del segundo un intento de soterrar el eco simbolista bajo el renacimiento de un gusto por lo clásico. La maraña que sus arranques y desencuentros tejieron contribuyó al cabo a la aproximación de autores de signo diverso, como así lo fueron Banville, Khan, Verlaine o Rimbaud, pulsaciones de un teclado multivocal en la estética europea finisecular. Voces diversas que tienen su eco en el artículo presente, bajo la batuta curiosa de Emilia Pardo Bazán. Conoceremos algunas de sus ideas sobre tal enjundioso asunto, revisando su producción. Con su pluma delinearemos algunos puntos del movimiento para rematar la obra con la recuperación de un texto olvidado de la autora, «Un poeta de la hora presente. Verhaeren», en el que otro creador simbolista campa delatando la versalitidad y claroscuros de su obra. Las dos partes de este trabajo, la rememoración del simbolismo en algunas de las notas que compusieron su peculiar sinfonía, y la edición de un texto olvidado de Pardo Bazán con el simbolismo de trasfondo, se complementan en un todo que no debe pasar desapercibido para el lector. Un todo que se traduce en la inclinación de una autora, Emilia Pardo Bazán, por las inquietudes intelectuales y el hormigueo cultural de su época, pasando ella por contradicciones, filiaciones y desencuentros con las estéticas fundamentales de la segunda 
mitad del XIX y principios del XX. El lector, advertido de la riqueza de una personalidad que todavía nos sorprende, digerirá con mayor placer todos los matices que se desprenden de su obra. Juzgue entonces.

\section{Algunas disquisiciones de Emilia Pardo Bazán sobre el Simbolismo}

Pardo Bazán, la mujer cosmopolita que viaja por Europa y asiste a las Exposiciones Universales de París, o contempla en la tertulia de la misma ciudad en casa de los Goncourt a figuras esenciales en este artículo como Huysmans, mantuvo un ojo avizor ante la caldera literaria de su momento, presentando su mirada crítica frente a lo que surgía. El movimiento simbolista no fue caso aparte, con lo que perfiló su visión oscilante sobre los vástagos de la corriente. Percibamos que la asombró, a veces en el desconcierto y en algún momento bajo el recelo, un movimiento exento de toda nota concomitante a las tendencias que lo precedían por edad, como el naturalismo o el realismo, destilados ellos con las peculiaridades del caso español (un naturalismo desvirtuado y un realismo bajo los focos del Siglo de Oro hispánico) frente a los basales de fundación (el francés, por ejemplo). Piénsese en esta frase para clarificar lo aducido: «El simbolismo siempre será enigmático cuando no vaya tan vestido de carne como en el Quijote, donde acaso es involuntario» ${ }^{1}$.

Conviene desmenuzar, para entender la visión de la escritora, los comentarios de su obra, desde los acercamientos en el XIX («Últimas modas literarias», un botón en el ojal de muestras) hasta el XX con las sugestivas digresiones en El lirismo en la poesía francesa, La literatura francesa moderna. El naturalismo, La literatura francesa moderna. El romanticismo y La literatura francesa moderna. La transición. A ello se deben sumar otras fuentes, como Porvenir de la literatura después de la guerra (lectura en la Residencia de Estudiantes el 5 de diciembre de 1916). Este recorrido permite abordar los precursores del Simbolismo como Víctor Hugo, Gautier o Baudelaire, hasta llegar al encuentro de los autores que saciaron su sed con el manantial de esta estética (Mallarmé, Rimbaud, Verlaine, Wilde, Maetterlinck) o con su esencia destilaron nuevos rumbos (Huysmans).

Advirtamos de entrada que disquisiciones más detalladas sobre el movimiento conviven con evocaciones esporádicas que pueblan la producción de la escritora, evidenciando su interés y la importancia de dicha corriente. Introduzcamos, como apertura, el comentario del libro En plena bohemia de Gómez de Carrillo. Esas líneas le sirven de impulso para examinar a algunos de los autores próximos al simbolismo; musicalidad, evocación onírica, artificio y modelaje del ritmo ocuparán el centro de abundantes comentarios pardabazanianos. Una sugestión por el movimiento que lleva a apreciaciones anacrónicas en las que ve como primera muestra de la corriente a Prudencio, en tanto que «fenómeno sensible como figura y señal de la vida interior» (El lirismo en la poesía francesa, 45).

De la definición que Pardo Bazán aporta sobre el caudal simbolista fructifican varios brotes. Primero, son los simbolistas los que buscan la «idea en la oscuridad del lenguaje» (La literatura francesa moderna. El naturalismo, 121). Segundo, están llamados a con-

\footnotetext{
${ }^{1}$ «La vida contemporánea», en La Ilustración Artística de Barcelona, 21 de marzo de 1904, pág. 202.
} 
vocar una auténtica transformación literaria, si bien se componen de autores de instinto aislado carentes de una cumbre, de un genio iluminador; esto es,

el movimiento neo-ideal, en Francia, carece por ahora de jefes de genio robusto y arrollador: tiene oficiales y soldados muy distinguidos, pero le faltan generales. Acaso hay en su índole nebulosa, en su difuso misticismo, algo que repugna a la lucidez, precisión y sequedad del carácter y del idioma francés» (prólogo a Los hermanos Zemganno, de Goncourt, 1891).

Tercero, advirtamos nuevamente una Pardo Bazán al tanto de las nuevas tendencias, como ya vemos en «Últimas modas literarias» (La España Moderna, 1 de febrero de 1890). Comentando All vanguardia de Vittorio Pica valora en él los «estudios sobre autores también actuales», y cita a Verlaine, Mallarmé o Huysmans, entre otros (página 165) y confiesa la profunda impresión que le ha provocado la lectura de Verlaine (pág. 167), en especial sus poesías místicas. Repunta su asunción de la relevancia de este y Mallarmé en tanto que innovadores, las voces discortantes que amenanzan los cimientos de las corrientes en boga, actitud que les lleva a soportar los embites del status quo.

De 1890 a 1920 (el intervalo en el que aparecen los textos en este párrafo referidos) observamos alusiones, embebecidas de una concomitancia notable que facilitan vislumbrar cierto estado de la cuestión. Notas afines que sin embargo no impiden sutiles (no siempre) ambivalencias, notoriamente destacadas en sus semblanzas de los autores vinculados a la escuela. Es en este espéculo en el que se mira donde entona su preferencia por Verlaine frente a la oscuridad de Mallarmé, o su reivindicación de Wilde, o también su gusto a ratos arrobado por el ambiente parisino en el que se movían Verlaine o el Moréas de los textos que supuraban lirismo o mostraban la magia de su mejor obra, $\mathrm{Sa}$ lomé $^{2}$.

Con Pardo Bazán trazamos una línea ambulatoria que da hospedaje al decorrer del movimiento. Un decorrer que acoge a los que son considerados precursores o iniciadores de tal estética: Baudelaire, Verlaine, Rimbaud, Mallarmé; también los románticos Víctor Hugo (así lo afirma sin ambajes en La literatura francesa moderna. El romanticismo, 171) o Gerard de Nerval. El entendimiento de lo que de ellos dice nos dará luz sobre su concepción del movimiento simbolista.

De Nerval vemos en el capítulo XXVI de El lirismo en la poesía francesa la presencia de un autor próximo a Gautier. En tales páginas aparece el Nerval seducido por la demencia en un mundo rodeado de primeras figuras (Gautier, Víctor Hugo, Vigny...) así como el hombre cosmopolita, viajero, atraído por Oriente, imbuido en las notas que fascinarán a los simbolistas. Contemplamos al autor de Aurelia, el libro que delata indeludiblemente la condición del hombre perseguido por la locura. Al fin, el suicida, para la autora por ser precisos «el suicida romántico» en esencia. No sólo en Hugo o Nerval anota los elementos simbolistas, puesto que su análisis alcanza a La tentación de San Antonio de Flaubert (La literatura francesa moderna. El naturalismo, 59); o a Nana de Zola (La literatura francesa moderna. El naturalismo, 122). Se reviste de interés la paráfrasis y diegésis que la autora compone, dado que de ahí procede una aproximación a lo que ca-

\footnotetext{
${ }^{2}$ «Bohemia literaria», $A B C, 5$ de enero de 1920; «Decadente», $A B C, 10$ de enero de 1920.
} 
taloga como un idealismo de corte práctico y horizonte prosaico, sin la voluntad artística de la esencia de la escuela simbolista.

A mayores, las páginas paradobazanianas anuncian a Vigny como precursor del simbolismo, sobre todo en La cólera de Sansón, Eloa y La casa del pastor (La literatura francesa moderna. El romanticismo, 106). De igual forma, otro nombre, Gautier, es un predecesor; el genio romántico incomprendido; el referente de Baudelaire, de parnasianos como Leconte ${ }^{3}$. Según la óptica de la creadora gallega, la muerte del naturalismo conduce a una nueva concepción estética en la que el arte prevalece por encima de todo, llegando a la oscuridad a veces extrema ${ }^{4}$; e insiste en que Gautier es asimismo

maestro de parnasianos, enamorado de la plástica, tiene fe en la hermosura: no en la natural, sino en la del arte. Se consuela de la vida mediante la contemplación de las formas y los colores, tratados por ilustres artistas. Y, gracias a este sentido de la belleza plástica, sus versos no tienen la vaguedad lamartiniana; presta a la poesía la estructura, el brillo, el color, la precisión de contorno de los metales y las piedras preciosas que los incrustan. Los versos al cincel, lo lapidario, la descripción que vence a la pintura y a la escultura y al grabado y a la talla, proceden de Teo (La literatura francesa moderna. El naturalismo, 253254).

Gautier encarna el prototipo de creador del arte ensalzado por sí mismo, por encima de cualquier cosa (ibídem., 60), del precursor según se apostillaba del parnasianismo (ibídem., 249). La mano del poeta pergeña el juego de los sentidos, la plasticidad de los objetos, los colores, las formas, el hermanamiento con lo pictórico, el impulso pagano (ibídem., 253-254, 255, 286). Del pensamiento pardobazaniano se desprende su condición de creador de las transposiciones, esa fusión entre literatura y otras artes que juega con la plasticidad en la palabra, con la evocación del verso, influyendo en Baudelaire o Banville (La literatura francesa moderna. La transición, 271). Se concibe la acuarela del autor de minorías en el que tiene prevalencia el estilo y la procura de la Belleza, bajo una tonalidad sensual y un paganismo nuevo de tono antirromántico y afán netamente esteticista.

Con Baudelaire, el imprescindible Baudelaire para entender correctamente el simbolismo, alaba la capacidad del canto a lo que no se siente, lo que no se atesora como parte del sentimiento íntimo, pues en él triunfa el poder de idealizar y sublimar lo ajeno. Prueba indiscutible son sus composiciones dedicadas a las figuras de vírgenes católicas, flujo de un arrobo sin palpitar en él el fervor de la fe, como afirma la autora en $1913^{5}$. Baudelaire es el modelo que se instaura como ejemplo, como guía de la nueva sensibilidad poética ${ }^{6}$. Una sensibilidad distinta en la concepción del arte que

\footnotetext{
${ }^{3}$ «Crónicas de Europa. El centenario de Teófilo Gautier», «Crónica», en La Nación de Buenos Aires, martes 28 de noviembre de 1911, pág. 7.

${ }^{4}$ Lo dice en numerosas ocasiones. Además de las referencias que se van mencionando, piénsese en pinceladas como la que aparece en «Crónicas de España», en La Nación de Buenos Aires, viernes 10 de octubre de 1919, pág. 4.

${ }^{5}$ «La vida contemporánea», en La Ilustración Artística de Barcelona, 26 de mayo de 1913, pág. 346.

${ }^{6}$ Al pie de la torre Eiffel, «Los Goncourt».
} 
hermana lo siniestro con lo sublime, alcanzando su magisterio en campos lejanos como las cabezas cortadas de Valdés Leal7.

Bajo la retina pardozaniana Las Flores del mal son una estampa descarnada de la humanidad, expurgándose un espíritu católico desde los labios de un condenado ${ }^{8}$. Con su estudio es Baudelaire figura puesta en parangón con Musset, y se detalla que sus Flores del mal continúan la búsqueda mística que halla en la misma sociedad un encuentro interior (El lirismo en la poesía francesa, 356). La importancia de Baudelaire bajo la luz de Pardo Bazán guarda relación estrecha con que sea muestra de los grandes autores individualistas, como Verlaine (El lirismo en la poesía francesa, 249) y que se erija como autor consagrado a la belleza, al culto del arte por el arte ( $L a$ literatura francesa moderna. El naturalismo, 57). No es otro que el autor que contempla al mal y al pecado desde las membranas del catolicismo, propenso a lo artificioso en una huida frente a los elementos bregando contracorriente, el autor que grita

Je trône dans l'azur comme un sphinx incompris;

J'unis un cœur de neige à la blancheur des cygnes;

Je hais le mouvement qui déplace les lignes,

Et jamais je ne pleure et jamais je ne ris..

El simbolismo se asienta, según lo dicho, en otros nombres. Merced a ello, Verlaine se convierte, como contrapunto superior, en modelo comparativo de Moreau, por sus versos llenos de intimista entrega a la figura de la Virgen (El lirismo en la poesía francesa, 400); igual que ejemplo es aludiéndose a la religiosidad de Lamartine (El lirismo en la poesía francesa, 226). Las notas religiosas de su obra tronarán en otras páginas como ingrediente imprescindible (La literatura francesa moderna. El naturalismo, 205).

El devenir de las imbricaciones simbolistas supuso la aparición en escena de discípulos, seguidores de diferente rango que reivindicaban la imagen de un maestro. Así se percibe con la figura de Mallarmé al que observan René Ghil, Gustave Kahn o Henri de Régnier, entre otros que no despiertan sustancial interés en la producción de Pardo Bazán (nos viene a la mente Tristán Corbière, autor de menor calado según el juicio pardozananiano que lo carga con el fardo de ejemplificar una flor de un día ${ }^{9}$ ). La nómina de los que el simbolismo arrastró se incrementa con otras voces: Maurice Barrès, Paul Claudel, André Gide, Paul Valéry... Sobre ellos los juicios son de variopinto calado. Recordemos un nombre más: Óscar Wilde, el creador que muestra afinidades con el simbolismo y cultiva la premisa del arte por el arte bajo un esteticismo

\footnotetext{
${ }^{7}$ «La vida contemporánea», en La Ilustración Artística de Barcelona, 23 de junio de 1913, pág. 410; La literatura francesa moderna. La transición, 286-287.

${ }^{8}$ «Crónicas de España», en La Nación de Buenos Aires, domingo 4 de noviembre de 1917, pág. 5.

${ }^{9}$ «La vida contemporánea», en La Ilustración Artística de Barcelona, 14 de agosto de 1916, pág. 522.
} 
refinado. La admiración de Pardo Bazán es evidente, recreándose en una pleitesía ante la genialidad coartada del escritor inglés en una sociedad represora ${ }^{10}$.

El Kahn (1859-1936) de Domaine de fée es uno de los peor parados en el examen del movimiento. Ocurre con él que la escritora subestima su obra, hasta ponerlo a la altura de los que dan fruto efímero condenado a desaparecer sin mayor gloria ${ }^{11}$. Notas diferentes se entrevén respecto a Barrés al que considera fascinado por el carácter español, violento y enérgico, lleno de contrastes y matices ${ }^{12}$.

En nuestro recorrido es necesario dar un paso más. En la visión del simbolismo hay que comprender los lazos con sus congéneres y vástagos, en especial el parnasianismo (antesala del simbolismo) y el decadentismo (respuesta y redefinición de las emanaciones simbolistas). Pardo Bazán delató su interés por las formas parnasianas, como ocurre con Catule Mendès ${ }^{13}$, del que ofrece el perfil del escritor de raza, del poeta preferentemente romántico ${ }^{14}$, del imitador de Gautier o Baudelaire. La autora enconmia del parnasianismo el gusto por la forma, el cuidado esmerado del estilo, y le sirven estos postulados para reivindicar la figura de Mendès a su modo de ver infravalorada. Su estampa recorre acontecimientos de génesis múltiple como la iniciativa de Mendès, junto a Ricard, de promover ese nuevo movimiento cuyos maestros eran Leconte, Banville y Baudelaire, movimiento bajo tratado iniciático con El parnaso contemporáneo en 1866. De ahí arranca el parnasianismo en cuya nómina la autora inscribe a Verlaine, Coppée, Heredia, Villiers de 1 Isle-Adam, Mallarmé o Prudhomme (La literatura francesa moderna. El naturalismo, 248). Grupo dispar, según ella reconoce (demasiado heterogéneo, quizás), bajo un referente, Leconte de Lisle, y asume a Gautier y a Vigny como sus precursores, como también lo son del simbolismo. Con Mèndes, reconoce su valía en medio de múltiples reticencias. Así lo reitera en 1913, rememorando el olvido lastrado por la incapacidad de Catule de forjar una personalidad propia, supeditado a una poesía bajo el magisterio de otros (Gautier, Banville, Villiers de 1'Isle Adam o Leconte de Lisle ${ }^{15}$ ).

Asimismo, Leconte de Lisle es el autor de pulsión parnasiana que revela un alma misántropa y desdeñosa (La literatura francesa moderna. El naturalismo, capítulo XI). Su figura entraña la participación en el nacimiento de la corriente. Con Pardo Bazán conocemos la hecatombe de la escuela y la escisión, hasta el nacimiento de una nueva manera de concebir lo lírico, el simbolismo. Escisión promovida quizás por lo que su obra tiene de ajena al mundo real, evasiva, extasiada, fugitiva en la búsqueda de nuevos mundos, sensual:

\footnotetext{
10 «Bohemia literaria», ABC, 5 de enero de 1920; El lirismo en la poesía francesa, 240, 439; «La vida contemporánea», La Ilustración Artística, 27 de mayo de 1912, número 1587; «La vida contemporánea», La Ilustración Artística, 23 de junio de 1913, número 1643; «La vida contemporánea», La Ilustración Artística, 1 de junio de 1914, número 1692; «La vida contemporánea», La Ilustración Artística, 17 de mayo de 1915, número 1742; «Decadente», ABC, 10 de enero de 1910; «Crónica de Madrid», La Nación de Buenos Aires, viernes 1 de abril de 1910; «La vida contemporánea», La Ilustración Artística, 21 de agosto de 1916, número 1808; «Crónicas de España», La Nación de Buenos Aires, miércoles 12 de diciembre de 1917.

${ }^{11}$ «La vida contemporánea», en La Ilustración Artística de Barcelona, 14 de agosto de 1916, pág. 522.

12 «La vida contemporánea», en La Ilustración Artística de Barcelona, 1 de noviembre de 1897, pág. 827.

${ }^{13}$ «La vida contemporánea», en La Ilustración Artística de Barcelona, 1 de marzo de 1909, pág. 154.

14 «Crónica. El teatro en Francia-Hervieu», en Diario de la Marina, 25 de julio de 1909.

15 «La vida contemporánea», en La Ilustración Artística de Barcelona, 17de marzo de 1913, pág. 186.
} 
J'invoque Bakkhos qui donne le vin, qui, tournant autour des demeures Kadméiennes, arrêta les tremblements de terre. Quand la splendeur du feu envahit toute la terre, il enchaîna seul les tourbillons stridents de la flamme. Viens, bienheureux Bakkhos au cœur bienveillant.

De bestias y seres monstruosos, de pugnas contra lo divino, de atónitas imágenes y ambientes exóticos y estampas a ratos marmóreas, carentes de sentimiento, en un afán panteísta.

Con respecto a Banville lo cita como maestro de autores decadentes, junto a Baudelaire, Verlaine y Mallarmé, comentando poemas del conde Santibáñez del Río ${ }^{16}$. Advirtamos bajo las páginas de Pardo Bazán al Banville, igualmente progenitor del parnasianismo, defensor de la musicalidad en el verso, de la fascinación ante el mundo griego, el amante de la rima, del juego con la palabra (La literatura francesa moderna. El naturalismo, 253-257). De él procede el ansia por una rima que requiere ser dominada, como forma de exaltación del verso (La literatura francesa moderna. La transición, 217, 311), y manifiesta un intimismo muy personal (La literatura francesa moderna. El romanticismo, 108).

Si el parnasiamismo habita la antesala, el engorde y debacle del simbolismo generará a su vez efectos colaterales. De esta forma, de los descendientes de la tendencia nacerán otras maneras de entender lo lírico: un simbolismo exarcebado se equipara a lo que podemos llamar decadentismo. «Es la reacción contra lo tosco de ese mismo sentido democrático; contra la sequedad científica; es el sentimiento y el refinamiento y el cansancio de una civilización agotada, que reclama su fórmula en el arte» ${ }^{17}$, anticipado por la tonalidad satánica de un Barbey d'Aurevilly al que la autora contempla alejado de la esencia romántica y próximo a una estética diferente, neófita ${ }^{18}$. En similar posición está Huysmans, el réprobo con fe según Pardo Bazán, de ahí su desesperación sui generis ${ }^{19}$; el autor que busca la provocación, con Lá bas (El lirismo en la poesía francesa, 174). O Mirabeau, y su Jardín de los suplicios, viaje a la perversidad y al mundo de lo exótico ${ }^{20}$.

En fin, habla la escritora de un decadentismo que nace del Romanticismo, si bien los ropajes son de tela diferente. El decadentismo, asentando su cosmovisión, pierde la dimensión social y alcanza otra de pretensión individualista (El lirismo en la poesía francesa, 26), «hasta llegar a proponer, en tiempos más recientes, como ideal la perversidad, y como criterio de belleza la misma corrupción de las almas, refinada artísticamente» (ibídem., 248), fascinado por persojanes perversos como Nerón (ibídem., 366). Un decadentismo que es reflejo de una sociedad hastiada, decaída, ausente de ideales (La literatura francesa moderna. El naturalismo, 36) y que asienta una muestra de «misticismo modernista» (La literatura francesa moderna. El naturalismo, 163). En esa tónica juega Jean de Ripechin, cuya maestría en la versificación pone en Por Francia y Alemania («La poesía actual francesa. Ripechin») en la estela de Gau-

\footnotetext{
16 «Poetas», ABC, 3 de mayo de 1919.

17 «Crónica de Europa», en La Nación de Buenos Aires, jueves 20 de febrero de 1910, pág. 6.

${ }^{18} \mathrm{Al}$ pie de la torre Eiffel, «Un bizantino moderno».

19 «La vida contemporánea», en La Ilustración Artística de Barcelona, 14 de agosto de 1916, pág. 522.

${ }^{20}$ «La evolución de un género», $A B C, 12$ de diciembre de 1918.
} 
tier, Baudelaire o Banville. Un Richepin que bebe, a su modo de ver, de Barbier, Beranger, Baudelaire, Leconte o Víctor Hugo sin que ello sea impedimento para que forje una personalidad propia de afán revulsivo y nihilista. Con él Pardo Bazán alaba la capacidad de incorporar al verso elementos de germaníay argot callejero, muestra última de una intención polemista.

Si las líneas precedentes han jugado preferentemente en el campo de la lírica, permítasenos introducir a modo de contraste una óptica diferente desde la esfera de la dramaturgia. En este plano, en el del teatro simbólico, recuperemos la figura de Maetterlinck, el autor de grandezas y detalles sutiles como la obra para marionetas ${ }^{21}$. Pardo Bazán aduce elementos consonantes con lo propiamente espectacular paralelo a lo que entraña la puesta de escena. Están aquí las notas sobre las dificultades de representación de su obra o su aliento lírico. La autora detalla una situación ominosa, el escaso conocimiento en España del gran dramaturgo de lo que se salva La intrusa, texto al que considera como probable modelo en la poesía de Tagore (especialmente sobre Rey del salón oscuro ${ }^{22}$. Del estudio de Pardo Bazán despuntan su análisis de La sabiduría y el destino, donde ve cierta filosofía estoica, así como anotaciones como las alusivas al trágico peso sobre los personajes de su obra, un destino irrefrenable, un teatro «de la inconciencia», un puente entre vigilia y lucidez teñido de aires oníricos ${ }^{23}$. Autor de muchas caras que tiñe de misterio sus obras y convierte lo sugestivo en ingrediente base. En ello, hacia el final de su vida (en1917) la autora muesta especial cariño por $\operatorname{Los}_{\text {ciegos }}{ }^{24}$, la desgarrada pieza en la que un grupo de invidentes, perdidos a su suerte, afrontan un cruel y descarnado destino.

Todas estas luces no nos impidan, aun así, anotar las críticas, como las que vierte contra el libreto de Ariana y Barba Azul que este firma, con música de Dukas. Y es que Pardo Bazán no acepta la ambigüedad del mensaje, contraditorio en sus repliegues a ratos antifeministas, frente a otros de dirección diametralmente opuesta ${ }^{25}$. A estas alturas, en un 1913 en su arranque, el pensamiento pardobazaniano (ya conformado en lo que afectaba a estas lides) no podía estar favorable a tan desconcertantes bandazos.

Concluyamos este aportado teniendo presente las alianzas entre el simbolismo literario y el propio de otras artes, como la literatura o la pintura. Mucho habría que decir sobre ello, añadiendo las palpitaciones de textos pardobazanianos como La sirena negra, Dulce dueño o La Quimera (plagada de referencias plásticas, en una obra en la que el Arte se manifiesta en su esplendor, participando de estimulantes estéticos como el decadentismo en su más refinada y aquiescente perversidad). No nos detendremos ahora sobre ello, por escaparse a nuestros propósitos. Cerremos sin más aludiendo aunque sólo sea de manera tangencial al interés de Pardo Bazán por el simbolismo escultórico cor-

\footnotetext{
${ }^{21}$ «La vida contemporánea», en La Ilustración Artística de Barcelona, 11 de enero de 1904, pág. 42.

${ }^{22}$ «La obra de Tagore», ABC, 4 de mayo de 1921; «Crónicas de España», en La Nación de Buenos Aires, domingo 3 de julio de 1921, pág. 4 .

${ }^{23}$ «La vida contemporánea», en La Ilustración Artística de Barcelona, 21 de marzo de 1904, pág. 202.

${ }^{24}$ «Crónicas de España. Un ave de paso: Metterlinck», «Crónica», en La Nación de Buenos Aires, lunes 26 de marzo de 1917, pág. 6.

${ }^{25}$ «La vida contemporánea», en La Ilustración Artística de Barcelona, 3 de marzo de 1913, pág. 154.
} 
poreizado en $\operatorname{Rodin}^{26}$, del que aprecia su obra ${ }^{27}$; o la autora arrobada por el misterio que emana de la Salomé de Moreau ${ }^{28}$. No debemos extendernos por el momento. En este instante Verhaeren debe hacer sentir su voz.

\section{Un texto olvidado: «Un poeta de la hora presente. Verhaeren»}

El último apartado, tal y como se advertía al lector, ocupará algunas notas y una edición última de un trabajo olvidado que Emilia Pardo Bazán publica en la revista Cervantes en julio de 1917: «Un poeta de la hora presente: Verhaeren». Se centra de esta manera en una figura relevante en el panorama literario de entresiglos; es el Verhaeren de Los monjes y Los flamencos, obras más tempranas de tónica parnasiana; y Las campiñas alucinadas y de Las villas tentaculares, composiciones de talante simbolista, el que resulta de mayor calado para Pardo Bazán. Más que Las alas rojas, obra que este escribe en 1916 tras estallar la I Guerra Mundial como vehículo de exaltación de Bélgica, su país natal. Motivo por cierto que es en gran parte motor del artículo que escribe Pardo Bazán, sobre las posibilidades de una poesía épica o de la guerra.

El trabajo que se edita posee, así pues, varias implicaciones. La muerte del poeta, que se suicida arrojándose a las vías del tren, supone el motivo inicial para introducir el motivo del trabajo: las posibilidades de una epopeya que desmenuce la I Guerra Mundial. Para la autora, el intento de Verhaeren ha sido fallido en La Bélgica sangrienta y Las ciudades magulladas de Bélgica y, sobre todo, Las alas rojas de la guerra. Una apreciación inaugural le sirve de apoyatura a su juicio: la epopeya nace del canto del pueblo y la llegada de la Época Moderna supone el aletargamiento del canto épico. En esa perspectiva, la autora no identifica un genuino canto épico español, siendo lo más próximo La Aracauna de Ercilla.

El principal lastre que observa la escritora coruñesa es que la epopeya surge fruto de un engranaje de siglos que un poeta individual recoge finalmente. Por ello Verhaeren no puede lograr dicho pálpito porque es sobre todo poeta lírico, como Verlaine o Mallarmé; es el poeta de la alucinación. Pardo Bazán se hace eco de la conocida en la época como capacidad visionaria del artista belga, una dimensión de lo que es muestra señera el parnasiano Leconte. Aquí empezamos a vislumbrar los lazos con las corrientes líricas de finales del XIX, parnasianismo, simbolismo y decadentismo.Ante la evidencia de que Verhaeren aparezca casi ignorado en la crítica francesa, Pardo Bazán parafrasea los juicios de Rémy de Goncourt que censura el tono prosaico del autor. A la par, tal juicio da pie a que coincida con él en el magisterio de Víctor Hugo sobre Verhaeren. Un Víctor Hugo que emerge como maestro de las escuelas precedentes, como veíamos antes, sin que Hugo sea uno de los autores predilectos de doña Emilia (mientras afirma que sí lo son Heine o Verlaine).

En suma, el trabajo que ahora se ofrece detalla como Pardo Bazán alaba la plasticidad del retrato en Las flamencas y la belleza en Los monjes. Menos agrado le producen

${ }^{26}$ «Crónicas de Europa. El centenario de Teófilo Gautier», «Crónica», en La Nación de Buenos Aires, martes 28 de noviembre de 1911 , pág. 7.

${ }^{27}$ Cuarente días en la exposición, «Muñecos insurrectos»; «Crónicas de España», en La Nación de Buenos Aires, sábado 19 de abil de 1919, pág. 4.

${ }^{28}$ «Bohemia literaria», $A B C, 5$ de enero de 1920. 
los textos próximos, según ella, al sentir decadentista porque desde su óptica no es ahí donde despunta Verhaeren, brillante en sus versos descriptivos volcados en la realidad (piénsese en el autor sencillo, como el pintor Wiertz, cuando se inspiran en lo cotidiano). Por tanto, Las alas rojas, el poema de tono bélico, se perfila como una obra menor para la autora, un texto que no alcanza el sentimiento de la gran epopeya y que en ningún caso constituye un canto de la guerra. Verhaeren se presenta desdibujado, acosado por retitencias de una Pardo Bazán proclive al arte flamenco (el volcado en la realidad) y por tanto reticente a las elucubraciones de los decadentes.

En este punto de la diégesis, dejemos al lector con la lectura del trabajo. La evocación lírica de los simbolistas dan la vez al agitado precipicio de las palabras. Al lirismo de la voz que descompone la obra del poeta muerto, del suicida que convierte la pasión de la letra desatada en carne.

\section{NOTA A LA EDICIÓN}

Se transcribe el texto modernizándose la ortografía y enmendándose las erratas. Se ha respetado la puntuación de la autora cuando no discrepaba con la norma actual.

\section{«Un poeta de la hora presente. Verhaeren»}

Cuando sucumbió a un vulgar percance ferroviario este escritor belga, díjose en letras de molde, insistentemente, que era el único capaz de cantar la epopeya de una guerra como la que estamos presenciando, de una guerra verdaderamente tentacular, que abarca, con sus prolongaciones interminables, a manera de pulpo gigantesco, a Europa y Asia, y ya amenaza comunicarse a la América del Norte y al Brasil. No sabemos lo que hubiese hecho Verhaeren; pero lo que tuvo tiempo de hacer demuestra que siendo Verhaeren, en efecto, un gran poeta, el tema sobrepuja a sus alientos, y le viene grande, lo mismo que vendría grande, seguramente, a todo vate de nuestros días. Para fundar un poco esta aserción, diré lo que entiendo acerca de la poesía épica y su posibilidad en nuestros días.

Que toda poesía inspirada en la guerra tiene que ser épica, si ha de responder esencialmente a su objeto, parece que no sea necesario demostrarlo, porque lo prueban los hechos. No ha de entenderse por épico solamente lo que reviste forma de epopeya, génericamente hablando. Apenas hay epopeya, entre las primitivas, basadas justamente en las guerras, no sólo de pueblos, sino de razas -como el Ramayana, el Mahabarata, y más tarde la Ilíada y la Odisea-, que no tenga sus fuentes mucho más allá de la obra del poeta, ya culto, ya en cierto sentido erudito, que les ha dado la forma en que las conocemos. Ha sido el pueblo en sus cantos espontáneos, en la creación continua de poesía que, al través de los siglos, viene realizando, quien suministra la materia épica, y de esta formacion lenta, natural, tenemos en nuestra literatura nacional un ejemplo claro y demostrativo. Los elementos que en Grecia y en la India han sido, por decirlo así, reabsorbidos por la raza, aquí todavía podemos reconocerlos y los descubre la investigación cuando busca los orígenes del Romancero y hasta los de los poemas del Cid. Hay más: tenemos en gran copia esos componentes, esa materia épica difusa, y nos falta la epopeya propiamente dicha. Es en nuestro teatro y en Zorrilla donde fueron a perderse, como riachuelos en el mar. 
Desde los mismos orígenes de la epopeya ha latido en su seno el fermento lírico. Sobre la magna e inconsciente obra de las colectividades surge la del individuo, que reclama sus derechos. Los reclama primero tímidamente, sin atreverse a luchar con tradiciones, religiones, instituciones seculares; todo ello pesa sobre el sentimiento individual, y lo hace como pudoroso, secreto, y, más que nada, ajeno a toda reivindicación de derecho alguno. Sin embargo, un día tras otro día, el individualismo acaba por imponerse, y se puede afirma que, así como la edad primitiva y sus derivaciones hasta entrado el Renacimiento pertenecen a la epopeya, la Edad moderna pertenecerá enteramente al lirismo y el elemento épico irá desapareciendo, secándose como un árbol al cual se le han cortado las raíces.

He aquí, a mi entender, la razón por la cual las epopeyas antiguas no reflorecieran, y la última sapiencial y magnífica fue La divina comedia. Ya sabemos que España no tuvo epopeya oficial, y con haber hecho nosotros las cosas más épicas de cuantas sucedieron en el mundo, lo único realmente inspirado, a trechos, que en el género produjo nuestra musa fue La Araucana, de Ercilla. La riqueza épica atesorada en nuestras entrañas fueron las redacciones más o menos tardías del Romancero, y la bullente expansión del teatro, en el cual lo épico culmina sobre lo lírico, aunque el lirismo individualista haya puesto su sello más hondo en personajes como el Segismundo de La vida es sueño, y Casandra, la heroína de El castigo sin venganza.

Parecerá que estoy yéndome a enorme distancia de Verhaeren... No por cierto. Para decir que no pudo Verhaeren ser el poeta de la guera, el cantor épico de una patria y una nación oprimida, pisoteada, lacerada; para afirmar que no cabía en lo lógico el que lo fuese, había que empezar reconociendo que la epopeya organizada es un género desaparecido. La evolución de los géneros es un estudio de historia natural literaria que ha sido hecho detenidamente casi como pudiera hacerse en un laboratorio, y se ha visto que la epopeya no nació jamás de la inspiración de un solo hombre, sino que es resultado de la creación legendaria colectiva, creación que dura bastante tiempo, siglos, antes de que la concentre y recoja el poeta que ha de fijar su forma duradera. Y esto que voy escribiendo no va contra el talento, contra las cualidades muy altas de Verhaeren: no pudiera él realizar un milagro, alterando todas las leyes de la morfología literaria.

Ante todo, hay que tener en cuenta que Verhaeren no es tampoco otra cosa que un poeta lírico, como lo son todos los de sus generación, Metterlinck en el teatro, y en la rima Verlaine, Mallarmé, y tantos y tantos como pudieran citarse. Verhaeren ha sido caracterizado como poeta de la alucinación, que es cosa muy lírica, una hiperestesia de la visión poética, en que adquieren alma todas las cosas, hasta las inanimadas, y hablan al espíritu.

Y este don de la alucinación constante, de sentir la vida intensa y visionaria, es ya un don poético, no cabe negarlo. Hay algo de profeta y de vidente en todo artista. Algunos, sin embargo, no prestan tal vivir misterioso a las cosas: las miran, al contrario, desde una altura serena, aunque en su fondo, trágica; y el mejor ejemplo de esta manera de ver es un poeta francés, Leconte de Lisle, jefe de la escuela parnasiana y maestro de los impasibles y olímpicos, que tiene la calma augusta de un mármol griego.

Busco en las historias de la literatura contemporánea francesas el nombre de Verhaeren, y debo declarar que encuentro en ellas y en los estudios críticos en gene- 
ral escasas referencias al poeta belga. Dijérase que le niegan, tácitamente, la alternativa. Puede esto achacarse a la nacionalidad de Verhaeren; pero, dado el espíritu hospitalario de Francia, y la aceptación que otorgó a los novelistas rusos y, en su día, a poetas como Heine, parece extraño que, en el campo de la crítica seria y metódica, hallen tan escaso ambiente Verhaeren y también Metterlinck. La guerra tal vez traiga, en este particular, una revisión de valores; entre tanto, transcribo el juicio de Rémy de Gourmont, heraldo de tantas reputaciones nuevas, y cuya manga más bien se puede calificar de anchísima, en bastantes casos.

Dice así el crítico del Mercure: «Verhaeren no ha dominado el idioma; sus más bellas páginas las doblega el peso de epítetos importunos; sus mejores poemas se encuentran atollados en lo que antes se llamaba el prosaísmo». Antes y ahora, porque el prosaísmo no ha dejado de existir, y de ser una condición, o, mejor dicho, un defecto de bastantes poetas; las causas serían largas de recontar.

Reconoce, sin embargo, Gourmont que la impresión producida por Verhaeren es de grandeza y vigor; $y$, como no podía menos de suceder, encuentra en el poeta belga a un descendiente directo de Víctor Hugo. Igual convicción sentí al leer algunos de sus versos, entre los cuales hay no pocos que Víctor Hugo pudiera firmar. Y esto, que en parte es un elogio, por otro lado indica en Verhaeren la filiación romántica. No he sentido hacia los imitadores de Hugo gran simpatía, y, después de inclinarme ante las dotes realmente asombrosas del maestro, ante el prodigio de su verbalismo, ante su autoridad imperial sobre el idioma, me he atrevido siempre, desde hace bastantes años, cuando todavía quedaban en España hugólatras fanáticos, sobesaltados al decir yo, en mis lecciones en la cátedra de Estudios superiores del Ateneo de Madrid, que Víctor Hugo, con ser un poeta tan inconmensurable, no era mi poeta. Y es que yo prefiero, a lo desmesurado, lo proporcionado, y, en poesía, hasta lo breve, y sobre todo, lo humano, lo profundamente saturado de humanidad y embebido de sentimiento. Así, en el siglo XIX, mis poetas han sido Enrique Heine, Musset, Verlaine, algunos otros que no hincharon la voz en la trompa.

Por lo que respecta a Verhaeren, no fue para él, tal vez, muy beneficiosa la escuela de Hugo. Los derroteros de su musa hubiesen sido más seguros quizás si caminara libre en los comienzos de su carrera poética, porque es un don precioso la independencia en la juventud, aun cuando nadie la haya ostentado completa y siempre se puedan observar influencias en los más grandes.

Verhaeren ha producido mucho; tengo a la vista más de una docena de libros suyos, abundando las colecciones de versos: a ellos hay que añadir algunos tomos en prosa y los dramas, entre los cuales figura aquel Felipe II que ha venido a dejar tamañitos a Alfieri y Schiller, en cuanto a pintorescas invenciones acerca de la figura del príncipe don Carlos. No insistiremos mucho sobre este aspecto de la obra de Verhaeren, y nos limitaremos a hablar de su poesía, antes y después de la guerra.

Los tres tomos de Poemas -series las titula el autor- dan ya completa idea de su personalidad. La primera serie comprende el ciclo de las impresiones familiares, de la Flandes castiza. Así el poema con que se abre el volumen -en la edición que leo- produce el efecto de un lienzo o tabla de los clásicos pintores de la escuela más sometida a las influencias ambientes que se ha conocido en el mundo: la de Teniers, Steen y Brauwer. Cuelgan en el lar jamones y morcillas y, del techo, racimos de perdices y ocas rellenas y 
resplandece la panza de los calderos y las mujeres ríen, cantan, beben, igual que sus compañeros de material orgía: explosión, dice el poeta, de instintos y de apetitos, de furores de estómago y vientre, de libertinaje y de glotonería desatada.... A lo vivo está la pintura, como las restantes de la coleccioncita que el autor titula Las flamencas. La lira se hace pincel, cediendo así a la fuerza tradicional; el arte plástico se impone a la poesía y la hace descriptiva; Gourmont diría prosaica, amiga del detalle crudo y de la pincelada crasa y jugosa. Así exclama, dirigiéndose a los artistas de aquella época: «Vuestras mujeres sudaban salud y estaban rojas de sangre y blancas de grasa...».

Ya es estos poemas asoma el peligro del elemento descriptivo, que si pone al poeta en contacto directo con la realidad externa, le quita mucho de aquella llama interior por medio de la cual la realidad se transforma. Ved el poema titulado «Las llanuras»; es pura descripción. De las restantes «flamencas» hay que alabar, por el mismo carácter pictórico, la vaquera que ordeña; la «manchita» de la leche en la cueva estrecha y baja, dentro de las jarras profundas; la enérgica agua fuerte de «Los cerdos»; la crudísima kermesa contenida en «Los labriegos». Estos poemas, que pueden calificarse de regionales, me han hecho pensar en la diferencia que va de región a región, en las manifestaciones de su poesía natural. Imagino los mismos temas tratados por un poeta regional de Galicia. También por allá hay romerías que equivalen a las kermesas, con todos los incidentes grotescos y sensuales que en éstas pueden producirse. También allá hay la «matanza», y los despojos del puerco se convierten en golosinas y no faltan rústicos oaristis, ni vaqueras, ni gañanes. Pero aunque según dicen los etnólogos, sangre céltica corre por las venas de los flamencos y de los gallegos, sin duda la de los flamencos es más gruesa y espesa y la materia, como en su pintura, se muestra en ella más. En lo gallego hay melancolía doliente y aguda ironía riente y más espiritualidad, no cabe duda. Tal vez ni los labriegos sean en Flandes tan sensuales y tan negros, groseros y bestiales como Verhaeren los describe en estos poemas, que considero, por otra parte, de lo mejor que ha hecho y de los más sincero y fuerte. El mismo, cantando a las mujeres de otro tiempo, dice que «concentran nuestro ideal carnal». El ideal gallego, que hasta poco ha no tuvo pintores, no es un ideal carnal, o lo es sólo en ciertos aspectos.

Pero no olvidemos que el país de esos pintores que han inspirado los versos de Verhaeren, los pintores de las cínicas kermesas, de las mujeres regordetas y sin pudor, es también el país donde el arte concibió la visión célica, sublime, del Cordero místico. Y de tal cuadro, único entre las obras del humano arte, hay un reflejo en la colección titulada Los monjes, donde vemos la inspiración católica del ascetismo:

Et, parvenus au temple, ouvrant pour eux son choeur.

Sous un recourbement d'ogives colossales,

Ils tombent a genoux sur la froleur des dalles.

Et jettent vers leur Dieu tout le sang de leurs coeurs.

Le sang frappe 1' autel et sur terre s'épanche;

Il rougit la splendeur des murs éblouissants,

Mais quoi qu'ils aient souffert depuis dix-huit cents ans.

L'hostie est demeurée implacablemente blanche. 
Sin duda no conocía Verhaeren un cuadro de uno de nuestros primitivos españoles, en el cual, sobe la hostia que el sacerdote alza, cae un chorro de sangre del costado de Cristo.

También esta colección de Los monjes -que me recuerda, en esta hora amarga para Bélgica, mi visita a la interesante abadía de Maredsus- es de lo mejor, de lo más sentido que ha cantado Verhaeren. Los poemitas titulados «Meditación», «Agonía de monje», «Muerte cristiana», bastan para consagrarle como gran poeta.

Quisiera que me agradasen tanto como Los monjes y Las flamencas las otras colecciones, muy numerosas, que Verhaeren ha publicado, y entre los cuales citaré otras dos series de Poemas y los titulados Las fuerzas tumultuosas, El múltiple esplendor, Las horas claras y Los semblantes de la vida. No pudiera negarse que, entre tanto verso, falten bantantes muy inspirados y muy impregnados de ese ardor sombrío y triste que caracteriza a Verhaeren; pero tampoco sería injusto afirmar que, para la gloria de este poeta, serían suficientes uno o dos volúmenes de versos, y en lo demás ha incurrido en los amaneramientos de la escuela decadentista.

No es fácil evitar la sorpresa leyendo versos como estos:

La lune est un bloc de folie;

La lune est une bouche de gel, Qui mord mon coeur essentiel

Cuando Verhaeren cae en estos laberintos, desciende su inspiración. Porque Verhaeren gana siempre que, olvidándose de las alucinaciones, se acerca a la realidad y ahonda en ella. No en balde es flamenco, no en balde empezó por beber en las fuentes de ese arte nacional de la pintura, que tantas enseñanzas de verdad contiene. Le sucede a Verhaeren algo de lo que a su paisano Wiertz, el pintor, cuyos extraños cuadros se enseñan en Bruselas. Cuando se sale de la realidad, va llegando, gradualmente, hasta lo cómico y caricaturesco del horror. No todos los pueblos producen artistas naturales del horror como nuestro Valdés Leal. Y el horror mismo necesita estar inspirado por la naturaleza, si ha de causarnos el escalofrío de lo bello.

En cambio, la nota sencilla es en Verhaeren muy penetrante. Se puede dar un volumen entero de alucinaciones por un poemita como el encantador titulado Los pobres y que, sin fraseo, dice tanto:

Il est aussi de pauvres coeurs,

Avec, en eux, des lacs de pleurs;

Qui sont pâles, comme les pierres

$\mathrm{D}$ ' un cimetière.

Il est aussi de pauvres mains,

Comme feuilles sur les chemins,

Comme feuilles jaunes et mortes,

Devant la porte...

Il est aussi des pauvres gens,

Aux gestes las et indulgents,

Sur qui s' acharne la misère.

Au long des plaines de la terre. 
La fina sobriedad de estos versos, su patética dulzura, los hacen semejantes a música de clavicordio antiguo. Y ni he citado el poema entero, ni podría, en un estudio sucinto, recontar las bellezas que a veces se descubren en Verhaeen, ni tampoco entretenerme en recoger pasajes en que el amaneramiento de la escuela le sugiere estrofas como la que sigue:

Et doux soleil que baise un oeil éteint d' aveugle.

Et fleur venué au tare décembral de l'hiver.

Et plumé d'oiselet soufflée au vent de fer?

Et neutre et vide écho vers faure qui meugle?

Tengo que pasar rápidamente por estos aspectos de la retórica de Verhaeren, para volver a lo que dije en los primeros párrafos: para examinar si, en efecto, Verhaeren hubiese podido ser el cantor de la guerra, el que recogiese, en su alma vibrante de poeta y de patriota, los ecos sonoros de esta horrenda lucha. Los que Verhaeren ha dejado y que se inspira en estos acontecimientos ultra trágicos es, amén de dos tomos de prosa, titulados La Bélgica sangrienta y Las ciudades magulladas de Bélgica, una colección de poemas, Las alas rojas de la guerra, que no falta quien considere obra maestra, en su terreno. Y por tal motivo, y por la confirmación que pudiese dar a las esperanzas cifradas en Verhaeren como Homero posible de esta Ilíada, si no hubiese tenido la desgracia de morir antes de ver redimida a su patria, me detendré un poco en el examen del libro.

Su génesis, la encontramos en uno de los libros en prosa, donde el mismo autor (en La Bélgica sangrienta) nos refiere como, de apasionado admirador de Alemania, se convirtió en su enemigo mortal ante los hechos de la invasión.

$\mathrm{Y}$ esto es tan natural, que lo asombroso sería lo contrario. Y la fuerza de este sentimiento poderoso y hondo, el amor y la defensa de la patria maltratada y sometida por la violencia es tal, que en un poeta verdadero bien pudiera hacer brotar la llama épica, si los tiempos en que vivimos lo consintiesen. Veamos lo que ha hecho Verhaeren bajo la presión de tales móviles psicológicos.

Ha hecho, sin duda, un cuadro lleno de verdad, descriptivo, demasiado descriptivo tal vez. La descripción, fiel y ahincada, no es, sin embargo, ni el grito vehemente del lírico, ni el cántico viril de la epopeya. En la Ilíada hay largas descripciones y campea en ellas la exactitud sorprendente, la fidelidad que en todo lo dependiente de lo real se nota en el sublime texto homérico, y que le da tal carácter de precioso aumento para conocer el período heroico de la historia; pero, por cima de esa exactitud de descripción, están los elementos psicológicos, los caracteres, las razas, en que culmina la epopeya. En el libro de Verhaeren, no diré que la descripción no sea profundamente artística. Es hasta como un cuadro en que la vista y los demás sentidos, como el oído, son afectados por la lucidez y viviente claridad con que el poeta recoge las impresiones:

Disséminant la guerre.

Par régiments entiers à travers monts et terres, Au long du sombre Oder et del 'Elbe et du Rhin, Claquent 


\section{Partout les plaques \\ Des ponts d' airain, Au passage volant et trépidant des trains.}

Hay en el ritmo, en el modo de manejar el metro, en la elección de las palabras, un acierto singularísimo de armonía imitativa, como hay la más grandiosa imagen en esta otra estrofa admirable:

Et tou à coup se dirigeant vers la Vistule,

Du fond des Ourals blancs et des Caucases bleus

L'innombrable Russie en bataillons houleux

Se précipite et s' accumule;

L' ordre s'y fait et les chevaux et les soldats

Frappent si fort le sol des marteaux de leurs pas,

$\mathrm{Qu}$ on dirait $\mathrm{q}^{\prime}$ avec eux marche en avant la terre.

Seguramente que Verhaeren no habría leído un renglón de Verdaguer; y sin embargo, esta estrofa me recuerta, por la sublimidad de la figura, aquella otra de $L$ ' Atlántida:

Van per muntar-se les tallantes proes.

Com al sol del desert enceses boes.

Per morir una o altra a revolcons;

I roda com un carro el tro de la guerra.

Fent en sos pòls sotraquejar la terra.

Temerosa com ells d' anar a fons.

El resto de la colección titulada Las alas rojas de la guerra, no raya a tanta altura como el hermoso poemita que cité y que lleva por epígrafe «El mundo se arma».

No faltan en ella trozos de sentimiento, muy patéticamente expresado, y está narrado con emoción el estrago de la catedral de Reims, los sufrimientos de los hospitales de sangre, el destripamiento de la tierra que sostenía a los humildes labradores, el éxodo doloroso de los que ven arrasados sus hogares y tienen que huir de ellos por los ásperos caminos. Y aunque pinta cuadros tan animados y típicos como el que se titula «Un soldado viejo», lo cierto es que, en el conjunto, se queda a gran distancia de lo que pudiera llamarse inspiración épica. Es el volumen una fila de impresiones, una glosa de temas que, sin poderlo remediar, nos recuerdan artículos de prensa, porque esto del olor a periódico es el gran escollo que la poesía moderna tiene que evitar, y no siempre lo evita, y a veces hasta lo busca; tal sucedió a Copée, por ejemplo.

Los versos que Verhaeren pudiese escribir si la muerte no le hubiese sorprendido ¿serían superiores en intesidad, en alcance, en energía, a los que esta colección contiene? ¿Llegarían siquiera al vigor de algunos de Víctor Hugo, cuya fuerza épica no puede negarse? La respuesta parece aventurada. Yo, por mí, diría que no, y hasta diría que el poeta de Las campiñas alucinadas y de Las villas tentaculares, de Las flamencas y de Los monjes, es mayor que el de Las alas rojas. Acaso, para abarcar y reflejar un tema tan desmedido, se necesite remansarlo, por el transcurso del tiempo, en los senos de la memoria. 


\section{CONDESA DE PARDO BAZÁN \\ Catedrático de la Universidad Central \\ Cervantes, Madrid, número XII, julio de 1917, pp. 17-34.}

\section{BIBLIOGRAFÍA}

\section{De PARdo BAZÁN.}

La cuestión palpitante (1891), Obras completas, tomo I, Madrid, imprenta de A. Pérez Dubrull.

- El lirismo en la poesía francesa, Madrid, Editorial Pueyo, [s.a.].

- La literatura francesa. El naturalismo (1911), en Obras completas de Emilia Pardo Bazán, vol. 41, Madrid, Renacimiento.

- La literatura francesa moderna. El Romanticismo (1911), Obras completas de Emilia Pardo Bazán ( $2^{\mathrm{a}}$ ed.), vol.37, Madrid, V. Prieto y Cía.

- Emilia Pardo Bazán. La obra periodística completa en La Nación de Buenos Aires (1879-1921), edición de J. Sinovas Maté, Salamanca, Diputación Provincial de A Coruña, 1999, 2 vols.

— Cartas de la Condesa en el Diario de la Marina. La Habana (1909-1915), edición de C. Heydl-Cortínez, Madrid, Editorial Pliegos, 2002.

- La vida contemporánea, edición facsimilar de C. Dorado, Madrid, Hemeroteca municipal de Madrid, Testimonio de prensa, número 5, 2005.

- Un poco de crítica. Artículos en el ABC de Madrid (1918-1921), edición de Marisa Sotelo Vázquez, Alicante, Publicaciones de la Universidad de Alicante, 2006.

\section{Sobre PARdo BAZÁn (SELECCióN).}

KroniK, J. W. (1989), «Entre la ética y la estética: Pardo Bazán ante el decadentismo francés», en M. Mayoral (coord.), Estudios sobre «Los Pazos de Ulloa», Madrid, Cátedra-Ministerio de Cultura, pp. 163-174.

LAtorre, Y. (1993), «El retablo del Cordero Místico de Van Eyck, símbolo espacio-vital en La Quimera, de Emilia Pardo Bazán», Cuadernos de Estudios Gallegos, XLI,106, pp. 503-510.

- (1997), «Emilia Pardo Bazán hacia el siglo XX: la estetización pictórica», en J. M. González Herrán (ed.), Estudios sobre Emilia Pardo Bazán. In memoriam Maurice

Hemingway, Santiago de Compostela, Universidade de Santiago-Consorcio de Santiago, pp. 197210.

- (1999), «Lo monstruoso en Pardo Bazán», Brujas, demonios y fantasmas en la literatura fantástica hispánica, en J. Pont (ed.), Lleida, Universitat, pp. 205-216.

- (2002), Musas trágicas (Pardo Bazán y las artes), Lleida, Pagès editors, Universitat de Lleida.

LóPEZ SANZ, M. (1978), «En torno a la segunda manera de Pardo Bazán: Una cristiana y La prueba», Hispanófila, 63, pp. 67-68.

- (1978b), «Naturalismo y Espiritualismo en Los Pazos de Ulloa», Revista de Estudios Hispánicos, 123 , pp. 353-371.

- (1979), «Moral y estética fin de siglo en La Quimera de Pardo Bazán», Hispania,62, 1, pp. 62-70.

- (1981), «A propósito de La Madre Naturaleza de Pardo Bazán», Bulletin Hispanique,

Madera Seoane, M. J. (1993), «La reelaboración de motivos decadentistas: Emilia Pardo Bazán y Villiers del Isle-Adam», en G. Lavergne (ed.), Hommage à Nelly Clémessy, Nice, Université de Nice, II, pp. 411-420. 